\title{
PENGEMBANGAN HUTAN ADAT TARUPRAMANA DI DESA BATUBULAN KECAMATAN SUKAWATI KABUPATEN GIANYAR
}

\author{
N.W. Suniti ${ }^{1}$, W.P. Windia ${ }^{2}$, N.L.R. Purnawan ${ }^{3}$, I.A. Arthayani ${ }^{4}$
}

\begin{abstract}
ABSTRAK
Kegiatan pengabdian kepada masyarakat ini bertujuan untuk pengembangan hutan adat dalam rangka menjaga kelestarian lingkungan adat budaya Bali dan daya tarik wisata ekologis melalui pembuatan kebun bibit, penanaman dan penataan tanaman taru pramana di Desa Batubulan kecamatan Sukawati Kabupaten Gianyar. Metode yang diterapkan dalam pemberdayaan masyarakat pada kegiatan Ibw (Iptek bagi Wilayah) adalah sebagai berikut : (1) Koordinasi dan komunikasi secara partisipasif dengan kelompok tani untuk membuat program mulai dari perencanaan, operasional dan evaluasi; (2) Penyuluhan untuk menyamakan persepsi dan pemahaman masyarakat mengenai inovasi atau program yang diterapkan; (3) Pelatihan untuk meningkatkan keterampilan mengenai terapan iptek yang dialihkan bagi masyarakat ; (4) Pendampingan yaitu pertemuan secara berkelanjutan antara pendamping dengan masyarakat sasaran sehingga iptek yang dialihkan dapat dilaksanakan secara mandiri oleh masyarakat. Hasil yang diperoleh menunjukkan bahwa kegiatan desiminasi iptek bagi wilayah di Desa Batubulan, kecamatan Sukawati, Kabupaten Gianyar dapat berlangsung dengan baik, adanya partisipasi aktif masyarakat dan adopsi iptek yang tinggi. Partisipasi aktif mitra pada seluruh kegiatan desiminasi teknologi cukup tinggi yaitu 68\%. Kemampuan adopsi iptek dan inisiatif mitra untuk memproduksi bibit secara mandiri baru mencapai 50\%.
\end{abstract}

Kata Kunci: iptek, tanaman taru pramana, tanaman upakara

\begin{abstract}
Community service activities is aimed at the development of indigenous forest in order to preserve the environment of indigenous Balinese culture and appeal of ecological tourism through the creation of nurseries, planting and plant arrangement taru pramana in Batubulan Sukawati Gianyar Regency. The method applied in community empowerment activities IbW (science and technology for the Region) is as follows: (1) Coordination and communication are participatory with farmers' groups to create a program from the planning, operational and evaluation; (2) Guidance for the perception and understanding of the innovations or programs implemented; (3) training to improve the skills of applied science and technology being transferred to the public; (4) Assistance is ongoing meetings between the chaperone with the target communities so that science and technology are transferred can be carried out independently by the community. The results obtained show that the dissemination of science and technology activities for the regions in Batubulan village, sub-district Sukawati, Gianyar can take place properly, the active participation of society and the adoption of science and technology is high. Active participation of partners in all activities of technology dissemination is high at $68 \%$. Adoption of science and technology capabilities and partners' initiatives to produce seeds independently is quite high at $50 \%$.
\end{abstract}

Keywords: technology inovation, taru pramana plants, ritual plants

\footnotetext{
${ }^{1}$ Dosen Fakultas Pertanian Universitas Udayana, sunitiwayan@gmail.com

${ }^{2}$ Dosen Fakultas Hukum Universitas Udayana, windiapendet@yahoo.com

${ }^{3}$ Dosen Fakultas Ilmu Sosial dan Ilmu Politik, ramaswati.purnawan@gmail.com

${ }^{4}$ Dosen ISI Denpasar
} 


\section{PENDAHULUAN}

Desa Batubulan termasuk Kecamatan Sukawati berada pada ketinggian antara 0 - $450 \mathrm{~m}$ diatas permukaan laut dengan luas wilayah 1.004 ha. Mata pencaharian penduduk sebagian besar adalah kerajinan patung padas yang mendorong penggalian batu padas semakin intensif sehingga berdampak buruk bagi kelestarian lingkungan. Strategi yang diambil oleh Pemerintah Kabupaten Gianyar untuk mengatasi hal tersebut dengan penghijauan lahan bekas galian batu padas, jurang di tepi sungai dan lahan adat lainnya dengan tanaman bambu dan taru pramana. Permasalahan yang dihadapi oleh masyarakat adalah penyediaan bibit bambu dan taru premana yang masih sulit, sementara teknologi pembibitan jenis tanaman tersebut belum dapat dikuasai secara mandiri oleh masyarakat adat. Berdasarkan hal tersebut dilakukan alih teknologi pembibitan tanaman bambu dan taru pramana berbasis desa adat.

\section{METODE PELAKSANAAN}

Metode yang diterapkan dalam pemberdayaan masyarakat pada kegiatan IbW adalah sebagai berikut : (1) Sosialisasi dan penyuluhan untuk membangun persepsi dan pemahaman masyarakat mengenai inovasi atau program yang diterapkan, (2) Pelatihan dan simulasi mengenai terapan iptek yang dialihkan bagi masyarakat dan (3) Pendampingan yaitu pendampingan secara berkala dan berkelanjutan antara pendamping dengan masyarakat.

Pelaksanaan kegiatan alih teknologi stek pucuk untuk perbanyakan tanaman bambu dan taru pramana untuk merehabilitasi lahan yang rusak akibat penggalian batu padas adalah sebagai berikut:

(1) Kordinasi dan komunikasi secara partisipasif dengan masyarakat sasaran untuk merumuskan program mulai dari perencanaan, operasional dan evaluasi

(2) Peyuluhan tentang pentingnya alih teknologi perbanyakan tanaman dengan stek pucuk untuk menghasilkan bibit dalam jumlah banyak

(3) Pelatihan untuk membuat stek pucuk tanaman bambu dan taru pramana untuk penghijauan lahan yang rusak

(4) Pembuatan kebun bibit dan pendampingan produksi bibit dari stek pucuk melalui bimbingan teknis secara berkala dengan kelompok petani dan memberikan kesempatan untuk konsultasi menyangkut solusi dari berbagai persoalan terkait dengan aplikasi teknologi tersebut

\section{HASIL DAN PEMBAHASAN}

Kegiatan ini dilaksanakan di kelompok tani di Desa Batubulan Kecamatan Sukawati Kabupaten Gianyar yang beranggota 20 0rang selama 8 bulan (Maret - Oktober 2016). Desiminasi teknologi dilaksanakan melalui kegiatan sosialisasi dan persiapan materi, kegiatan penyuluhan dan pelatihan singkat yang dipusatkan di kebun pembibitan taru pramana serta kegiatan pendampingan melalui pembuatan nursery (kebun bibit ) masyarakat selama 4 bulan (April - Juli 2016). Iptek yang dideseminasikan di mitra adalah alihteknologi pembuatan bibit teru pramana dengan teknologi stek pucuk untuk menghasilkan bibit dalam jumlah besar dalam waktu singkat. Evaluasi kegiatan dilakukan pada setiap sub kegiatan melalui : (1) Evaluasi tingkat mitra; (2) Evaluasi penguasaan /daya adopsi iptek; (3) Evaluasi terhadap kualitas produk iptek yang dihasilkan. Adapun nama dan jumlah bibit tanaman taru pramana yang ada di nursery Batubulan adalah sebagai berikut 

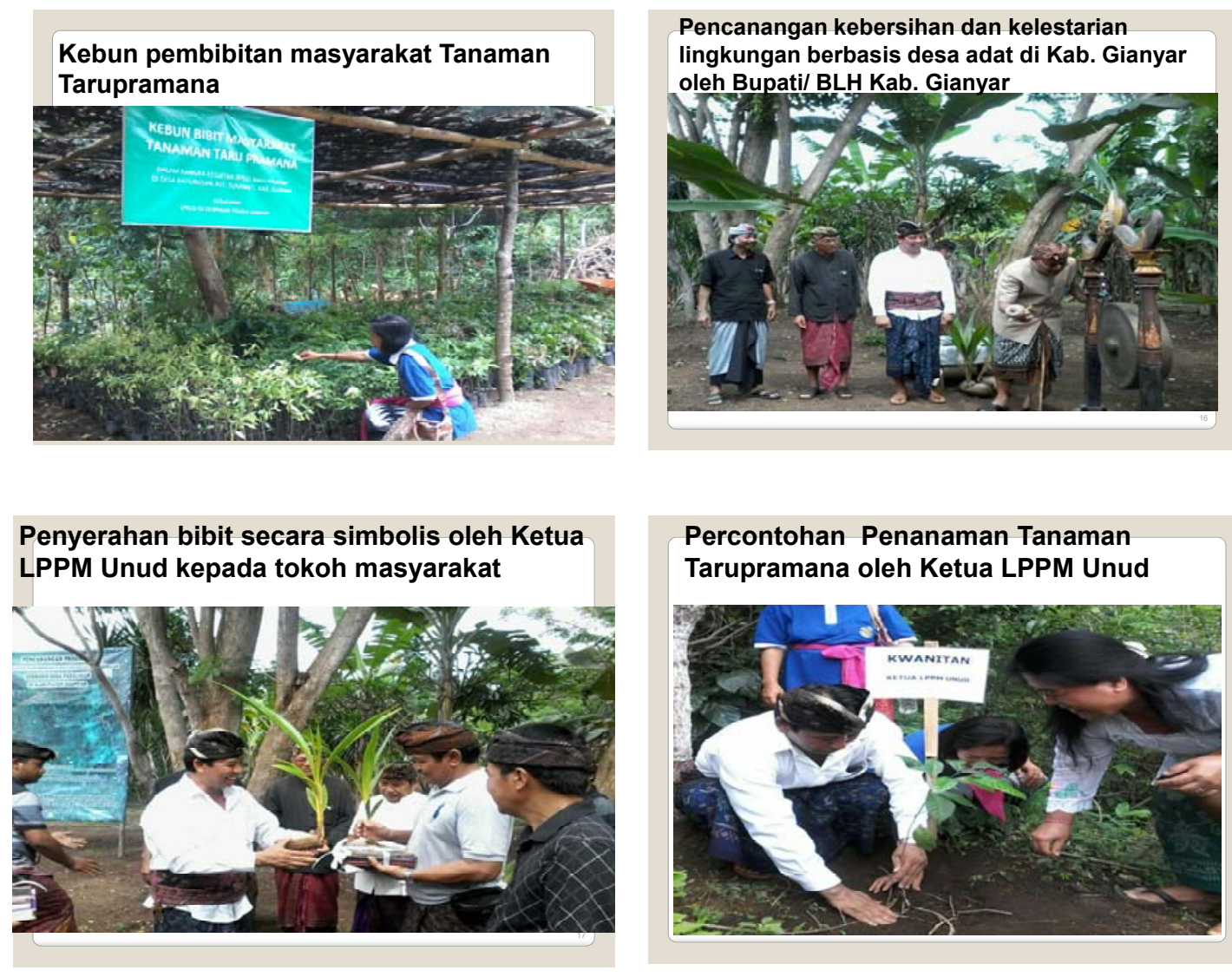

Percontohan Penanaman Tanaman

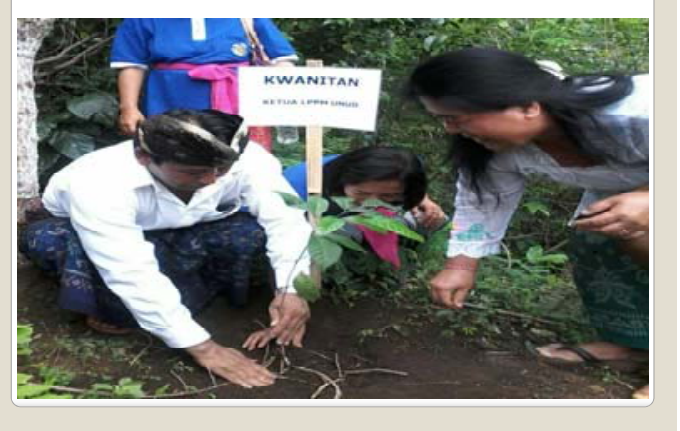

Tabel 3.1. Nama dan Jumlah Bibit Tanaman di Nursery Batubulan

\begin{tabular}{|l|l|c|l|}
\hline \multicolumn{1}{|c|}{ Jenis Tanaman } & Volume & \multicolumn{1}{c|}{ Manfaat } \\
\hline 1. & Merbau/ipil & 20 & Bahan bangunan \\
\hline 2. & Ampupu & 100 & Bahan bangunan \\
\hline 3. & Kwanitan & 20 & Bahan bangunan \\
\hline 4. & Mahoni & 20 & Bahan bangunan \\
\hline 5. & Bentawas & 50 & Bahan bangunan \\
\hline 6. & Cempaka & 100 & Bahan bangunan \\
\hline 7. & Boni & 18 & Bahan bangunan \\
\hline 8. & Nyamplung & 50 & Bahan bangunan \\
\hline 9. & Bambu & 100 & Penghijauan pantai \\
\hline 10. & Gaharu & 100 & Obat \\
\hline 11 & Cemara pantai & 10 & Penghijauan pantai \\
\hline 12. & Cendana & 458 & Bahan bangunan/upakara \\
\hline 13. & Majegau & 367 & Bahan bangunan/upakara \\
\hline 14 & Nagasari & 54 & Upakara \\
\hline 15. & Mundeh & 13 & Upakara \\
\hline 16. & Kelapa & 300 & Upakara \\
\hline
\end{tabular}

Pelaksanaan kegiatan pada mitra dapat berjalan dengan baik dengan peran serta mitra yang cukup tinggi mulai dari peninjauan lapangan, pemantapan lahan, persiapan lahan, pembersihan lahan, pembuatan bedengan untuk pembibitan dan pembuatan rumah pembibitan (nursery). Kegiatan penyuluhan yang dilaksanakan di kebun pembibitan masyarakat dihadiri oleh $100 \%$ anggota mitra dan $20 \%$ anggota mitra mengajukan permasalahan terkait produksi bibit taru pramana dan cara penanaman serta pemanfaatan tanaman tersebut. Pada saat kegiatan pelatihan pembuatan bibit 
menggunakan teknologi stek pucuk $100 \%$ anggota mitra hadir dan sangat bersemangat serta kegiatan berlangsung dengan baik. Dari 20 orang anggota kelompok, 10 orang (50\%) yang sudah mampu memproduksi bibit secara mandiri.

Tabel 3.2. Partisipasi Mitra dalam Kegiatan IbW

\begin{tabular}{|l|l|c|c|}
\hline \multirow{2}{*}{ No } & \multicolumn{2}{|c|}{ Kegiatan } & \multicolumn{2}{|c|}{ Mitra } \\
\cline { 3 - 4 } & & Jumlah (orang) & \\
\hline A & Kegiatan Penyuluhan-Pelatihan & 20 & 100 \\
\hline 1 & Absensi/Kehadiran & 10 & 50 \\
\hline 2 & Mengungkapkan masalah & 8 & 40 \\
\hline 3 & Ikut mencoba & & 100 \\
\hline B & Kegiatan & 20 & 50 \\
\hline 1 & Membantu produksi bibit & 10 & \\
\hline 2 & Memproduksi bibit secara mandiri & & \\
\hline
\end{tabular}

Berdasarkan Tabel 2 diketahui rataan partisipasi aktif mitra pada seluruh sub kegiatan adalah $68 \%$. Sedangkan inisiatif mitra untuk memproduksi bibit melalui teknologi stek pucuk baru mencapai $50 \%$. Hal tersebut menunjukkan bahwa adopsi teknologi produksi bibit melalui teknologi stek pucuk cukup berhasil.

\section{KESIMPULAN DAN SARAN}

1. Kegiatan desiminasi iptek melalui program IbW di Desa Batubulan, Kecamatan Sukawati, Kabupaten Gianyar dapat berlangsung dengan baik yang ditunjukkan dengan adanya partisipasi aktif masyarakat dan daya adopsi iptek yang cukup tinggi.

2. Partisipasi aktif mitra dalam seluruh kegiatan desiminasi teknologi cukup tinggi yaitu sebesar $68 \%$.

3. Kemampuan adopsi iptek dan inisiatif mitra memproduksi bibit secara mandiri baru mencapai $50 \%$

\section{UCAPAN TERIMAKASIH}

Penulis menyampaikan terimakasih yang sebesar-besarnya kepada Direktorat Riset dan Pengabdian kepada Masyarakat Kemenristek Dikti atas dana yang diberikan, Ketua Lembaga Penelitian dan Pengabdian kepada Masyarakat Universitas Udayana serta Desa Batubulan yang telah membantu kelancaran kegiatan ini.

\section{DAFTAR PUSTAKA}

Sardiana,I K.; Wayan P. Windia; Ketut Sudantra. 2011. Peta Desa Panduan Mengelola Konflik Batas Wilayah.

Sardiana, I K.; Ni Made Wiasti; I Noman Wardi dan Wayan P. Windia. 2013. Etnobotani Bali. 